\title{
Geociências
}

\section{Subvolcanic vent-filling welded tuff breccia of Cabo Frio Island, State of Rio de Janeiro, Brazil}

\author{
(Brecha soldada de preenchimento de conduto subvulcânico \\ da ilha do Cabo Frio, RJ)
}

\author{
Departamento de Geologia, Universidade Federal Fluminense \\ E-mail:susanna@igeo.uff.br
}

Akihisa Motoki
Departamento de Mineralogia e Petrologia Ígnea, Universidade do Estado do Rio de Janeiro
E-mail: rochasornamentais@yahoo.com.br

David Canabarro Savi

Instituto de Estudos do Mar Almirante Paulo Moreira

E-mail:david_canabarro@uol.com.br

Rodrigo Soares

Departamento de Mineralogia e Petrologia Ígnea, Universidade do Estado do Rio de Janeiro.

E-mail:roddrigoss@yahoo.com.br

\section{Resumo}

Na extremidade sudoeste da ilha do Cabo Frio, RJ, ocorre um corpo piroclástico exposto em uma área de 500 x 600 m, intrusivo no ortognaisse, com contato subvertical. Entre o ortognaisse e o corpo piroclástico, ocorre uma intercalação de traquito de 5 a 10 m de largura. As rochas piroclásticas têm estrutura suportada por clasto e matriz. Os clastos são de tamanho que variam de $1 \mathrm{~mm}$ a $40 \mathrm{~cm}$. Os clastos maiores do que 10 cm são semi-arredondados e os menores do que 5 cm são angulosos. Esses clastos são compostos principalmente de traquito, subordinadamente de ortognaisse e eventualmente de tufo soldado. A textura é heterogênea, não se observando seleção granulométrica e acamamento vulcânico. Ao microscópio, observa-se alteração hidrotermal caracterizada por disseminação de calcita, sericitização de feldspato alcalino e decomposição de minerais máficos. A matriz é preenchida por fragmentos angulosos de feldspato alcalino, quartzo, plagioclásio e minerais opacos, de tamanho menor do que 0,6 mm. A existência de clasto de tufo soldado indica que as erupções explosivas ocorreram repetidamente. O contato intrusivo subvertical, a pequena área de distribuição, o tamanho heterogêneo dos clastos e a ausência de acamamento vulcânico indicam que a rocha piroclástica corresponde à brecha soldada de preenchimento de conduto subvulcânico, e não constituinte de um depósito eruptivo subaéreo.

Palavras-chave: Ilha de Cabo Frio, conduto subvulcânico, rocha piroclástica, tufo soldado, contato intrusivo subvertical.

\begin{abstract}
At the southwestern corner of Cabo Frio Island, State of Rio de Janeiro, Brazil, a pyroclastic body is present in an area of $500 \times 600 \mathrm{~m}$, intruding into the host orthogneiss with subvertical contact. Between the orthogneiss and pyroclastic body, there is a trachyte intercalation, 5 to $10 \mathrm{~m}$ wide. The pyroclastic rocks have a clast-matrix supported structure and the clast size ranges from $1 \mathrm{~mm}$ to $40 \mathrm{~cm}$. Larger than $10 \mathrm{~cm}$ clasts are semi-rounded and those that are less than $5 \mathrm{~cm}$ are angular. They are composed mainly of trachyte, subordinately of orthogneiss, and eventually of welded tuff. The texture is heterogeneous and no grain-size sorting or volcanic layering of the clasts was observed. Microscopic observations have revealed hydrothermal alteration featured by calcite dissemination, alkaline feldspar sericitization, and mafic mineral decomposition. The matrix is filled by angular fragments of alkaline feldspar, quartz, plagioclase, and opaque minerals, smaller than $0.6 \mathrm{~mm}$. The existence of the welded tuff clasts indicates that explosive eruptions took place repeatedly. The subvertical intrusive contact, small exposure area, rounded clasts, heterogeneous clast size, and absence of volcanic layering indicate that the pyroclastic rock is subvolcanic vent-filling welded tuff breccia, and not a constituent of a subaerial eruptive deposit.
\end{abstract}

Keywords: Cabo Frio Island, subvolcanic conduit, pyroclastic rock, welded tuff, subvertical intrusive contact. 


\section{Introduction}

Along the coast of the State of Rio de Janeiro, Brazil, a dozen of late Cretaceous to Early Cenozoic felsic alkaline intrusive bodies is present (Ulbrich \& Gomes, 1981). Some of them, such as Itatiaia (Brotzu et al., 1997), Mendanha (e.g. Klein \& Vieira, 1980; Motoki et al., 2007a), Itaúna (e.g. Klein et al., 1999; Motoki et al., 2008a) and Cabo Frio Island (Lima, 1976), are accompanied by pyroclastic bodies made up mainly of volcanic breccia. There are controversial interpretations for their geologic emplacement mode: 1 ) subaerial eruptive deposits forming volcanic edifices (Klein \& Vieira, 1980; Klein et al., 1999); 2) vent-filling welded tuff breccia, constituting subvolcanic conduit emplaced at a kilometric depth (Motoki et al., 2007a; 2008a).

At the southwestern corner of Cabo Frio Island, Arraial do Cabo, State of Rio de Janeiro, Brazil, there is a pyroclastic body made up mainly of volcanic breccia. This body is well exposed on the sea-cliffs over $150 \mathrm{~m}$ high facing the Atlantic Ocean and its threedimensional form can be easily identified by fieldwork. The present article reports lithological, petrographical, and geological observations of the pyroclastic rock and considers its geologic emplacement mode.

\section{Regional geology}

Cabo Frio Island is located at $23^{\circ} \mathrm{S}$, $42^{\circ} \mathrm{W}$, being $126 \mathrm{~km}$ to the east of Rio de Janeiro City, comprising an elongated area of $4.4 \times 2.0 \mathrm{~km}$, with a total area of $6.5 \mathrm{~km}^{2}$ (Figure 1). The highest point is close to the old lighthouse, 390m above sea level. The entire island belongs to the environmental protection area, under administration of the Brazilian Navy Force.

The geology of this island is relatively little known and only a masterdegree thesis (Araújo, 1995) and some technical reports (e.g. Lima, 1976; Sichel et al., 2004) are available.

This region is underlain by the basement of leucocratic orthogneiss with amphibolite intercalations, $20 \mathrm{~cm}$ to $5 \mathrm{~m}$ thick. Up to the present, two ID-TIMS U-Pb datings by the discordant method have been performed. The upper intersection indicates $1975 \pm 6.5 \mathrm{Ma}$ (Schmitt et al., 2008), corresponding to intrusion age of the granitic protolith during the Transamazonian Event. The lower intersection is $501 \pm 6.0 \mathrm{Ma}$, showing metamorphic age as being the latest phase of the Pan-African continental collision event (Campos Neto, 2000), namely the Buzios Orogeny (Schmitt et al., 2008). The orthogneiss strikes $\mathrm{N} 5^{\circ} \mathrm{E}$ to $\mathrm{N} 15^{\circ} \mathrm{W}$ and dips $20^{\circ}$ to $40^{\circ}$ to the east, with local disturbances.
The basement is cut by Early Cretaceous tholeiitic dykes, 5 to $10 \mathrm{~m}$ thick, oriented $\mathrm{N} 55^{\circ} \mathrm{E}$. They are considered to be a part of feeder dykes of the Paraná Continental Flood Basalt (e.g. Peate et al., 1992), of the Ar-Ar ages raging from 129 to $134 \mathrm{Ma}$ (Turner et al., 1994). Recent studies demonstrated that the mafic dykes of the State of Rio de Janeiro are of about $137 \mathrm{Ma}$ (Guedes et al., 2005). At Arraial do Cabo, close to Cabo Frio Island (Figure 1), three unexpected young ages were obtained by Ar-Ar datings form low-Ti type dykes, about 55 Ma. However the age spectra are highly disturbed (Bennio et al., 2003).

Most of the area of the island is underlain by a syenitic intrusive body made up of nepheline syenite and alkaline syenite (Araújo, 1995), which cuts the basement and tholeiitic dykes. Previous works demonstrated that the syenitic body extends up to the peninsula of Pontal da Atalaia. However, recent studies (e.g. Motoki \& Sichel, 2008) have revealed that its distribution is, in fact, smaller than the above-mentioned estimation (Figure 1).

Western, southeastern, and eastern margins of this island are underlain by the orthogneiss and the southwest corner exposes the pyroclastic rock. In the orthogneiss area, three generations of dykes and sills are recognized (Motoki \& Sichel, 2008): The first generation is

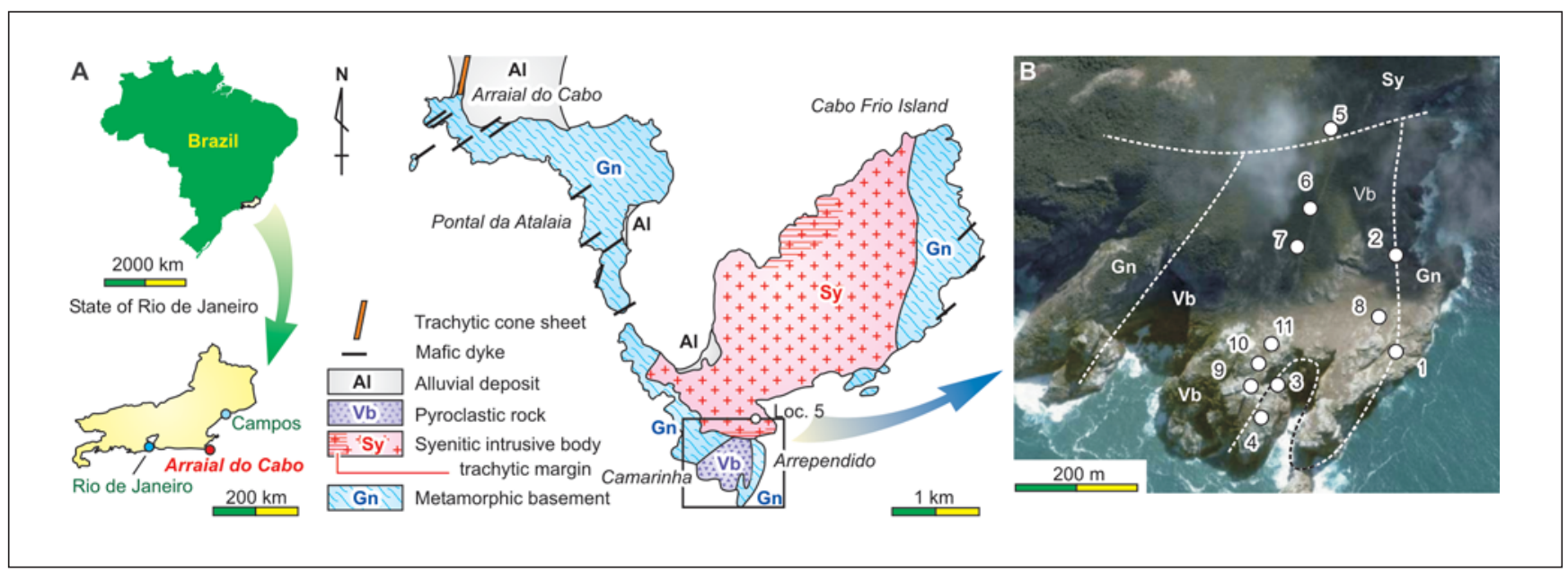

Figure 1 - Geological map of Cabo Frio Island (A) and site map of the studied area (B). The felsic alkaline intrusive bodies on the map of the State of Rio de Janeiro are: 1. Itatiaia; 2. Tinguá; 3. Mendanha; 4. Itaúna; 5. Rio Bonito; 6. Tanguá; 7. Soarinho; 8 . Morro de São João; 9. Cabo Frio Island. The satellite image is credited to Google Earth ${ }^{\mathrm{TM}}$. 
Susanna Eleonora Sichel et al.

composed of lamprophyre, older than the syenitic intrusion; the second generation is made up of trachyte with strong deuteric alteration, originated from the syenitic intrusion; the third generation is constituted by phonolite without deuteric alteration, the youngest of all.

\section{Contact relationship}

The pyroclastic rock occurs at an area with extension of $500 \times 600 \mathrm{~m}$ (Figure 1). Because of tropical weathering, only a few outcrops of the contact with the basement can be observed on the sea-cliff walls around the Arrependido fishing site (Loc. 1, 2; Figure 1B) and the Camarinha Cave (Gruta da Camarinha; Loc. 3, 4).
The contact plane between the pyroclastic body and the orthogneiss is subvertical, without intercalation of palaeo-soil and organic materials. The pyroclastic body has cylinder-like threedimensional form delimited by the intrusive contact. Between the pyroclastic rock and the orthogneiss, a trachyte intercalation, 5 to 10 m wide, is observed.

The contact outcrop at the Loc. 1 is situated at a slope which permits close observation by direct access (Figure 2A). The trachyte intrudes into the orthogneiss capturing it as xenoliths of metric size. Both trachyte and orthogneiss xenoliths are cut by the pyroclastic body (Figure 3). The mode of occurrence of the trachyte seems to be a dyke intruding into the orthogneiss and the pyroclastic body. However, the intrusive relationship between them is in fact the opposite.

The outcrop at the Loc. 2 occurs on a subvertical sea-cliff wall, with no direct access. Although the vertical contact can be recognized, the trachyte intercalation is difficult to be confirmed (Figure 2B). The wall in which Loc. 3 and 4 take place is parallel to the contact and shows trachyte intercalation (Figure 2C, D). Figure 4 presents the contact planes exposed on the sea-cliff at the Camarinha Cave as seen from the sea. Figure 5 presents a schematic geologic crosssection compiled from fieldwork data, showing the emplacement mode of this body as a pyroclastic neck.

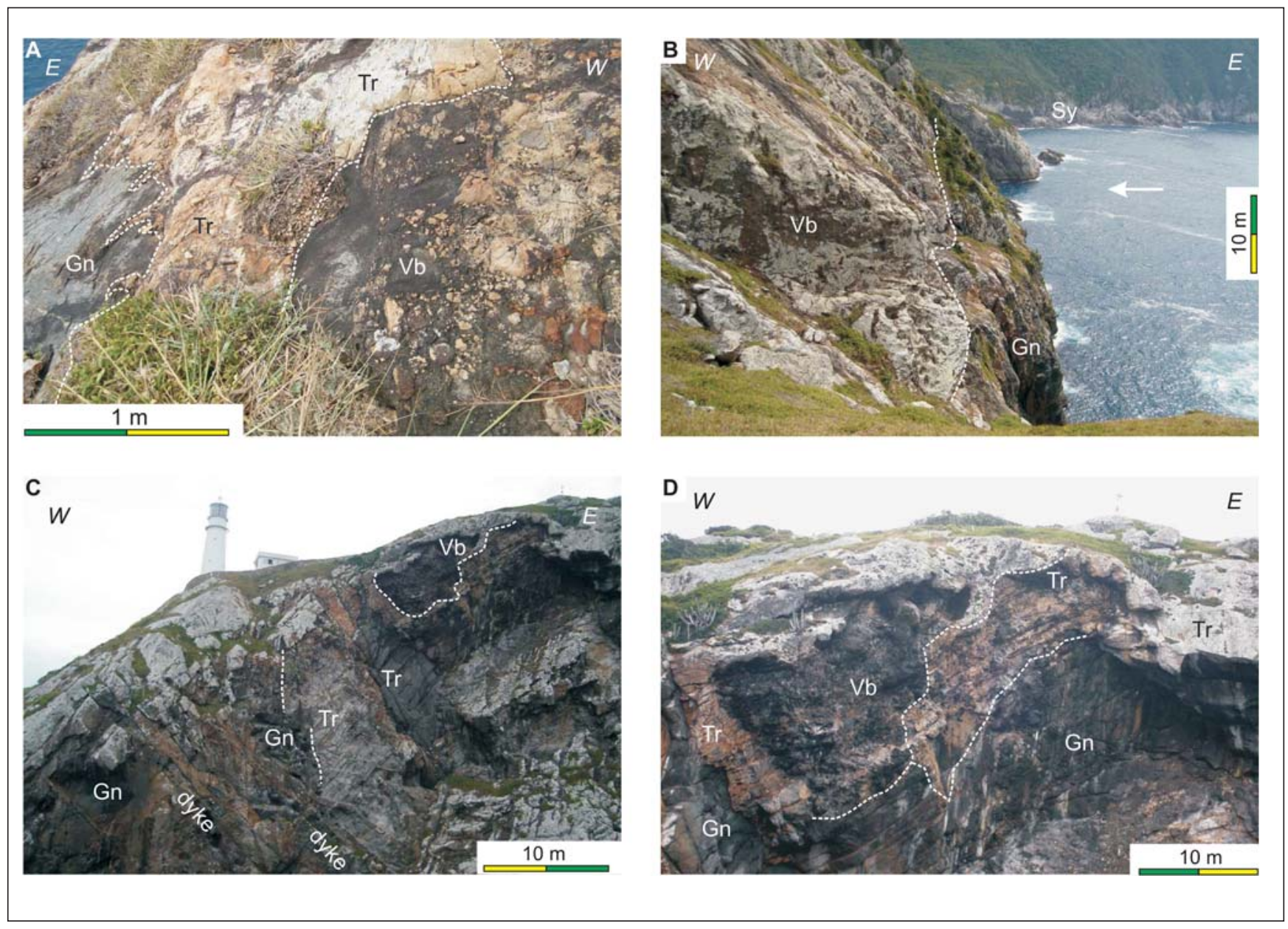

Figure 2 - Contact outcrops between the pyroclastic body and the basement orthogneiss: A) West of the Arrependido fishing site, Loc. 1; B) East of it, Loc. 2; C) Cliff close to the lighthouse, Loc. 3; D) Cliff at the Camarinha Cave, Loc. 4. The symbols are: Gn. basement orthogneiss; Tr. trachyte intercalation; Vb. pyroclastic rock made up mainly of volcanic breccia; Sy. nepheline syenite. The white arrow of photo $B$ is the viewpoint of the Figure $6 \mathrm{~A}$. 
The contact between the pyroclastic body and syenitic intrusion is exposed on the sea-cliff wall (Figure 6A). At the contact zone, well developed cooling joints are present. Although the exact contact has no direct access, a rock sample close to the contact has been collected. At this point, the syenite becomes finer grained, forming a chilled rim. This trachyte has aphyric microcrystalline texture composed mainly of alkaline feldspar of 0.07 x $0.2 \mathrm{~mm}$ with slight mineral orientation. All of the mafic minerals are altered into opaque ones (Figure 6B).

In the pyroclastic body, the first generation dykes composed of lamprophyre cannot be found. On the other hand, there are many second generation dykes of the trachyte with deuteric alteration, which are considered to be originated from the syenitic body (Motoki \& Sichel, 2008). The abovementioned observations indicate that the pyroclastic body is older than the syenitic body and younger than the lamprophyre dykes (Figure 7).

\section{Pyroclastic fabrics}

The pyroclastic rock contains relatively abundant clasts, showing a clast-matrix supported structure (Figure 8A; B). Matrix-supported (Figure 8C) and clast-supported structures (Figure 8D) also are found sometimes. In general, the clasts are less than $5 \mathrm{~cm}$ in diameter, being classified as lapilli, however, boulder-sized clasts can also be found eventually. The coexistence of large clasts and small ones in the same outcrop is commonly observed (Figure 8B).

The texture is highly heterogeneous and no granulometric sorting and volcanic layering of the clasts are present. Only the matrix-supported rock exhibits weak vertical layering parallel to the contact plain with the orthogneiss. The clasts are rounded to semi-angular (Figure 8C). In detail, the large ones, larger than $10 \mathrm{~cm}$ in diameter, tend to be rounded to semirounded, and the smaller than $5 \mathrm{~cm}$, are angular. Weathered surface shows a case-hardening crust (Figure 8B), which is commonly found in pyroclastic rocks (Motoki et al., 2007c).

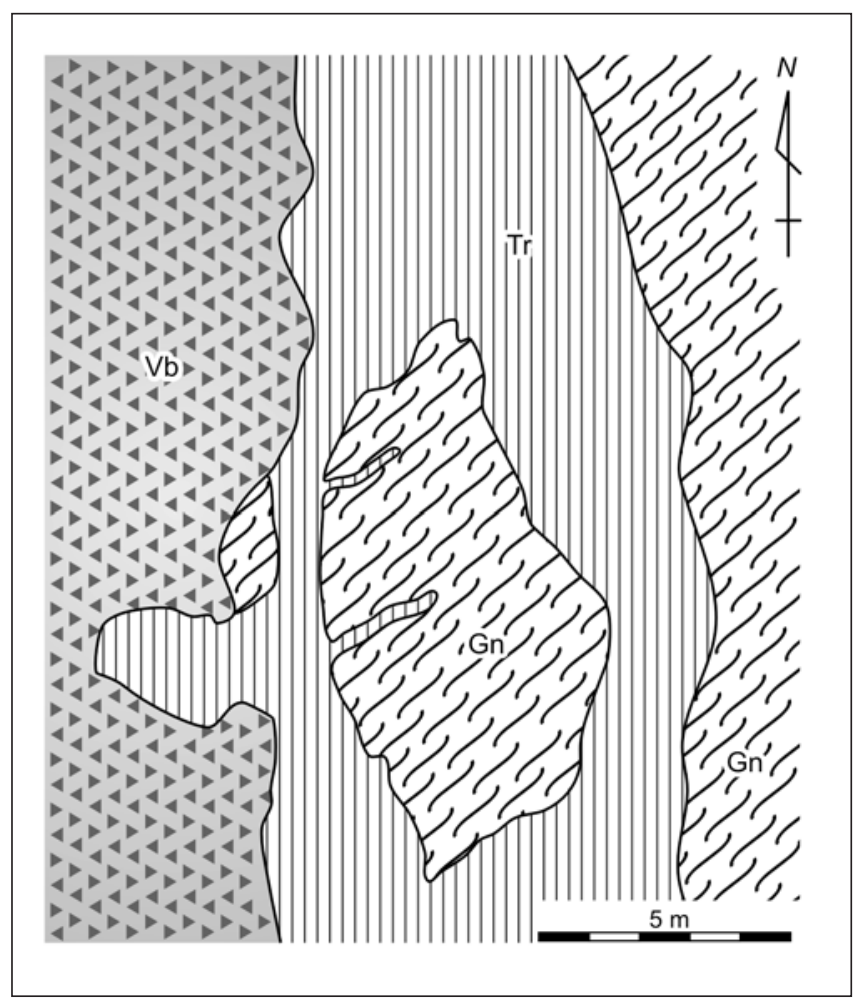

Figure 3 - Geological field sketch of the contact outcrop, Loc. 1. Note that the pyroclastic rock is younger than the trachyte. The symbols are: $\mathrm{Gn}$. basement orthogneiss; Tr. trachyte intercalation; $\mathrm{Vb}$. pyroclastic rock made up of volcanic breccia.

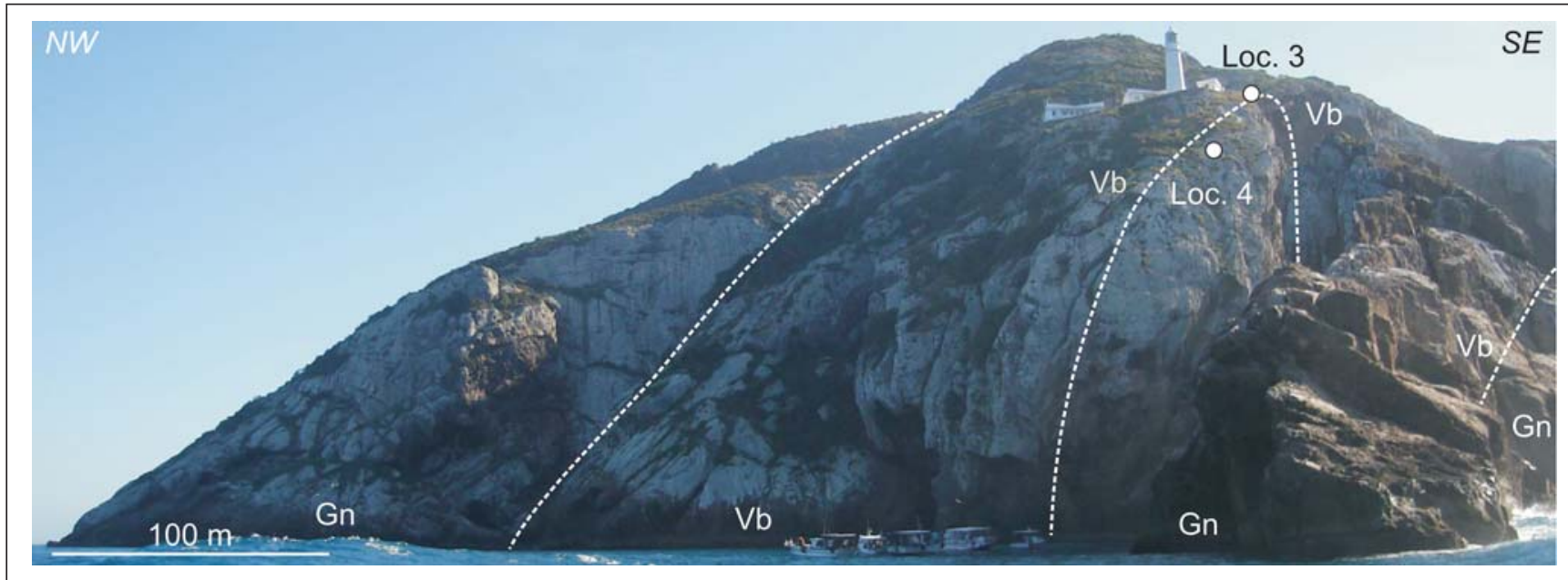

Figure 4 - Sea cliff outcrop at Camarinha Cave, southwestern corner of Cabo Frio Island (Loc. 3, 4), exposing the pyroclastic body made up mainly of volcanic breccia $(\mathrm{Vb})$ intruding into the basement orthogneiss $(\mathrm{Gn})$. The contacts are apparently oblique due to the outcrop cut angle effect, which is in fact subvertical. 
Susanna Eleonora Sichel et al.

Most of the clasts are composed of trachyte (Figure 8B), and some of them are made up of orthogneiss and pyroclastic rock (Figure 8A; D). The only accidental fragments are of orthogneiss, and clasts of alkaline syenite and nepheline syenite are not found. There are no essential vesicular fragments originated from magma drops, such as scoria, bomb and spatter (MacDonald, 1972). Although the main type of clasts is trachyte, this rock is a minor component of the wall rocks, being found as a small body at the contact plane (Figure 7).

The existence of welded tuff clasts (Figure 8A) indicates that, at least, one explosive eruption had occurred before the last explosive eruption that formed this pyroclastic body. During the last eruption, the trachyte and pyroclastic rock of the older stage were crushed and captured as accessory fragments.

\section{Petrographic characteristics}

The pyroclastic body is strongly altered and good samples for thin sections are difficult to obtain. Around the lighthouse, three good outcrops and one fresh angular boulder are found.
All of the thin sections show hydrothermal alteration represented by calcite dissemination, alkaline feldspar sericitization, and mafic mineral decomposition into opaque ones (Figure 9A; B). Some of the alkaline feldspar grains are altered into muscovite. The matrix is filled by small angular mineral fragments, less than $0.6 \mathrm{~mm}$ in diameter, of alkaline feldspar, quartz, plagioclase, and opaque minerals. Similar characteristics are observed in the pyroclastic dykes of the Mendanha body (Motoki et al., 2007c). The strong weathering of the pyroclastic body could have been induced by hydrothermal alteration.

Most of the clasts observed under microscope are of millimetric size. The most common rock is trachyte, about 60\% (Figure 9C), the second frequent one is orthogneiss, 35\%, and the other one is welded tuff, 5\% (Figure 9D).

The trachyte clasts are characterized by alkaline feldspar microliths with undulated orientation texture (Figure 9C). One microlith is in contact with another and no interstitial spaces are present. The size is widely variable depending on the clast, ranging from $0.02 \times 0.1 \mathrm{~mm}$ to $0.1 \times 0.5 \mathrm{~mm}$. The clasts of centimetric size contain alkaline feldspar phenocrysts of $0.2 \times 0.6 \mathrm{~mm}$ (Figure 9C).

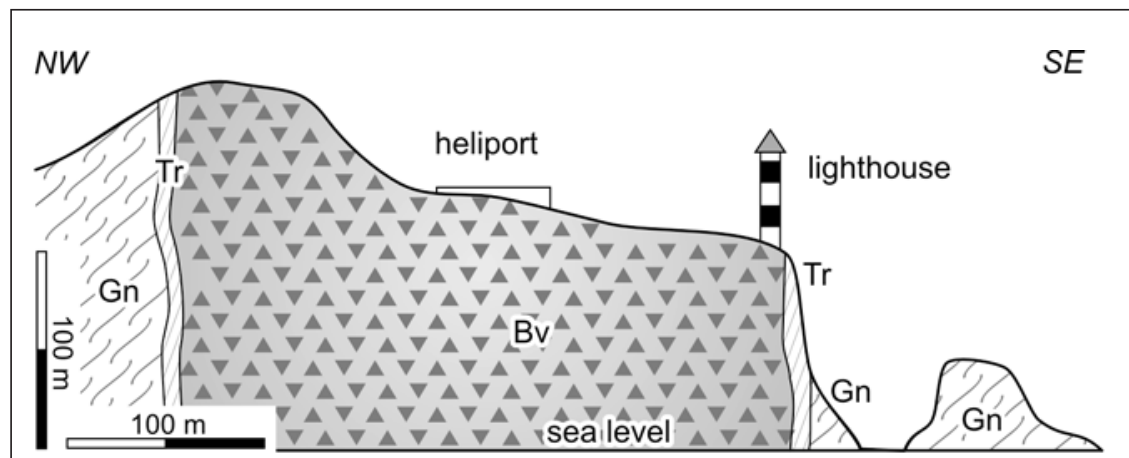

Figure 5 - Schematic geologic cross section of the pyroclastic body of Cabo Frio Island. The symbols are: Gn. orthogneiss; Tr. Trachyte intercalation; Vb. pyroclastic rock made up mainly of volcanic breccia.

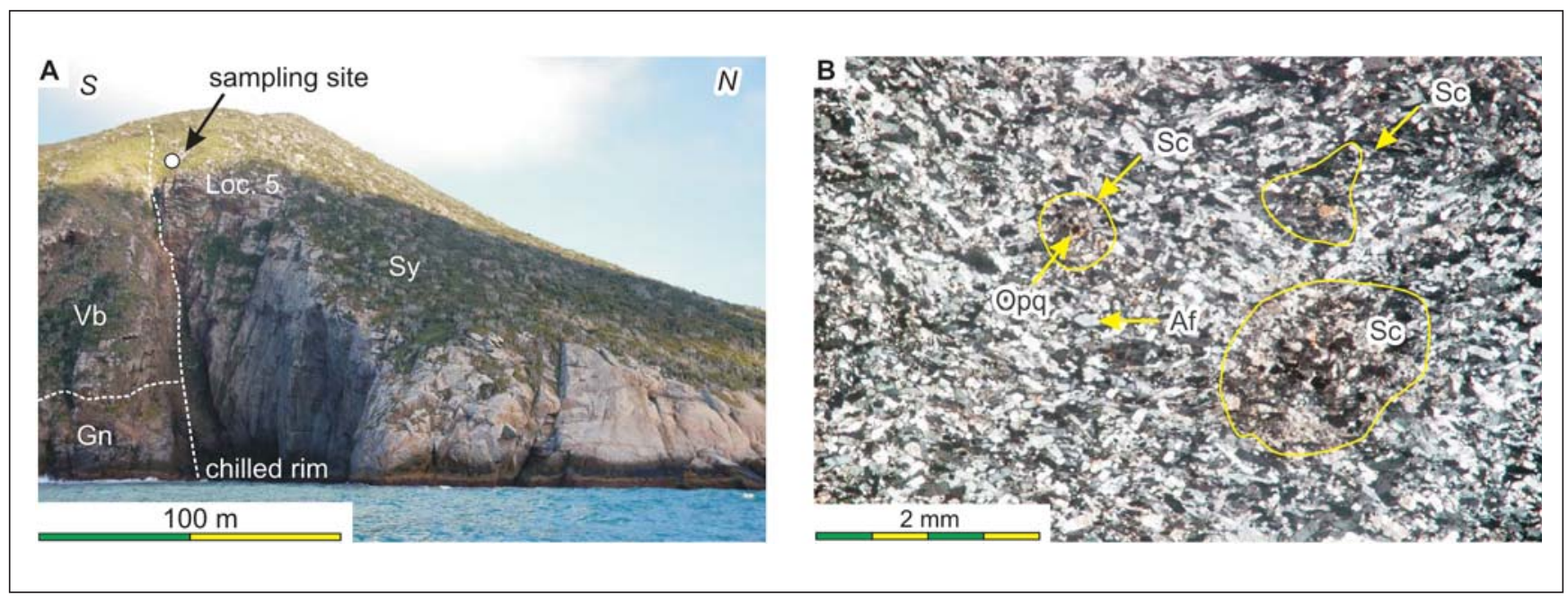

Figure 6 - Contact between the pyroclastic body and syenitic intrusion exposed on the sea-cliff, Loc. 5: A) view from the sea; B) photomicrography in crossed Nicol of fine-grained chilled margin of the syenitic intrusion. The components are: Gn. basement orthogneiss; Vb. pyroclastic rock made up mainly of volcanic breccia; Sy. nepheline syenite; Af. Alkaline feldspar; Opq. opaque mineral; Sc. Area of advanced sericitisation. 
There are some lithic fragments with micro syenite-like interstitial texture made up of tabular alkaline feldspar of $0.1 \times 0.5 \mathrm{~mm}$ (Figure 9E). The interstitial spaces are filled by alkaline feldspar and opaque minerals. The pyroclastic body is intruded by the syenitic body (Figure $6 \mathrm{~A} ; 7)$. In addition, the texture of the trachyte clasts is widely different from the chilled margin of the syenitic body (Figure 6B; 9E). Therefore, these clasts are not considered to be originated from the syenitic intrusion of Cabo Frio Island. They could be a variation of the abovementioned trachyte clasts. In the Itaúna rock body, gradual textural variation from a trachytic texture to an interstitial one was observed (Motoki et al., 2008a). The textural characteristics of the trachyte

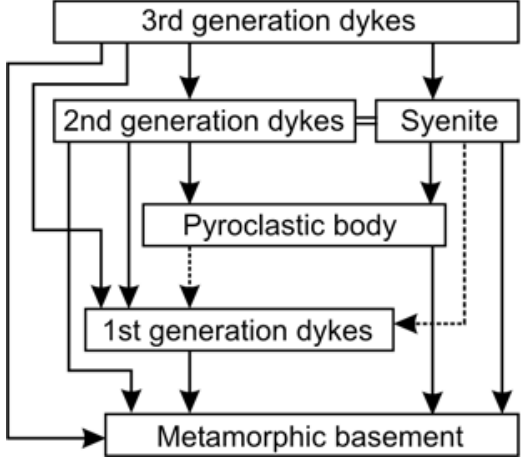

\section{Dyke generations}

3rd: Phonolite without deutric alteration 2nd: Trachyte with deutric alteration 1st: Lamprophyre

\section{Confirmed intrusive relation}

Supposed intrusive relation
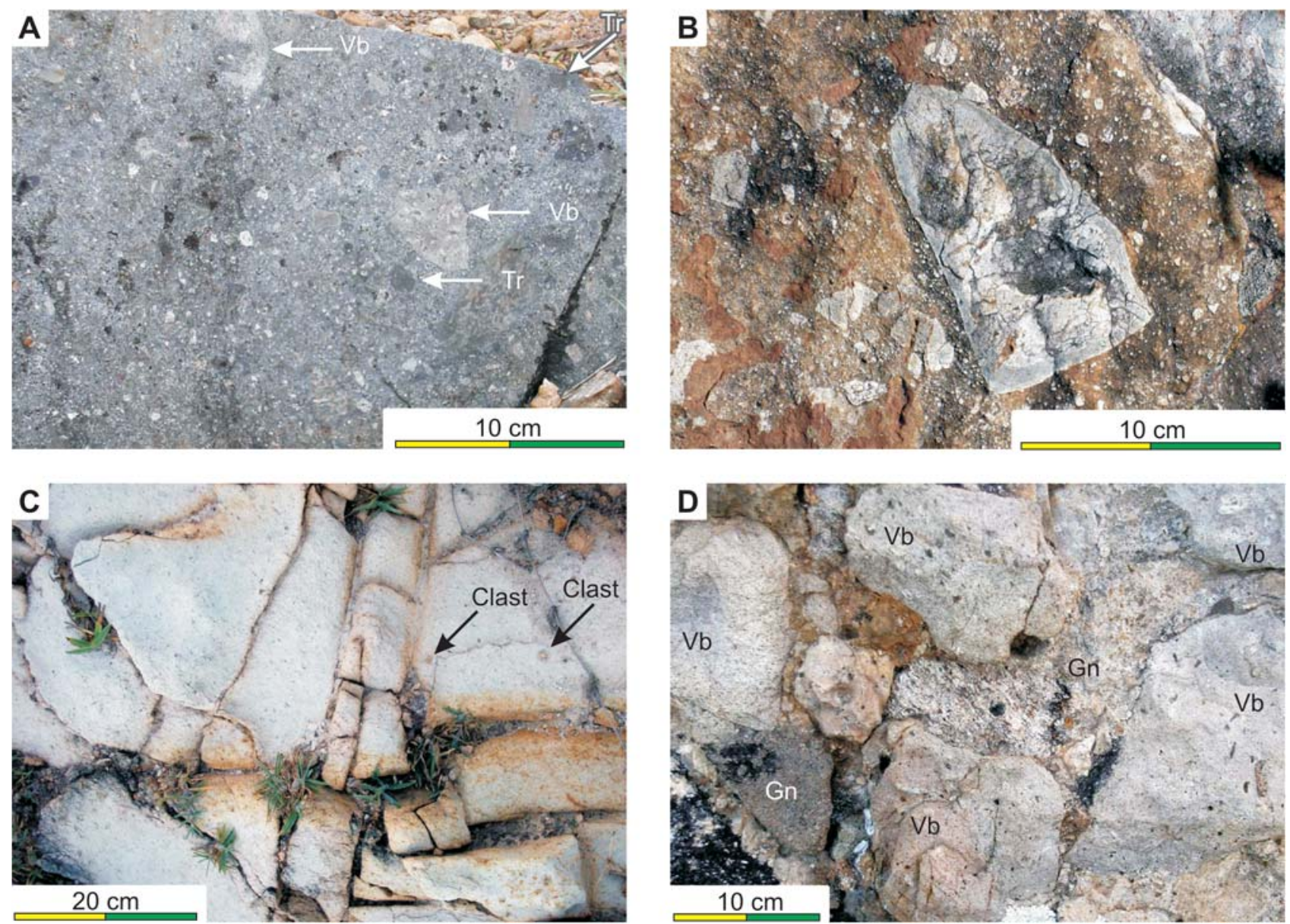

Figure 8 - Pyroclastic rocks of Cabo Frio Island: A) Fresh surface of an angular boulder with clasts of welded tuff (Vb) and trachyte $(\mathrm{Tr})$, Loc. 6; B) Large trachytic clasts with case hardening crust, Loc. 7; C) Matrix supported structure, with small amount of millimetric clasts, Loc. 8; D) Clast-supported structure with fragments of orthogneiss ( $\mathrm{Gn}$ ) and pyroclastic rock of older stage (Vb), Loc. 1. 

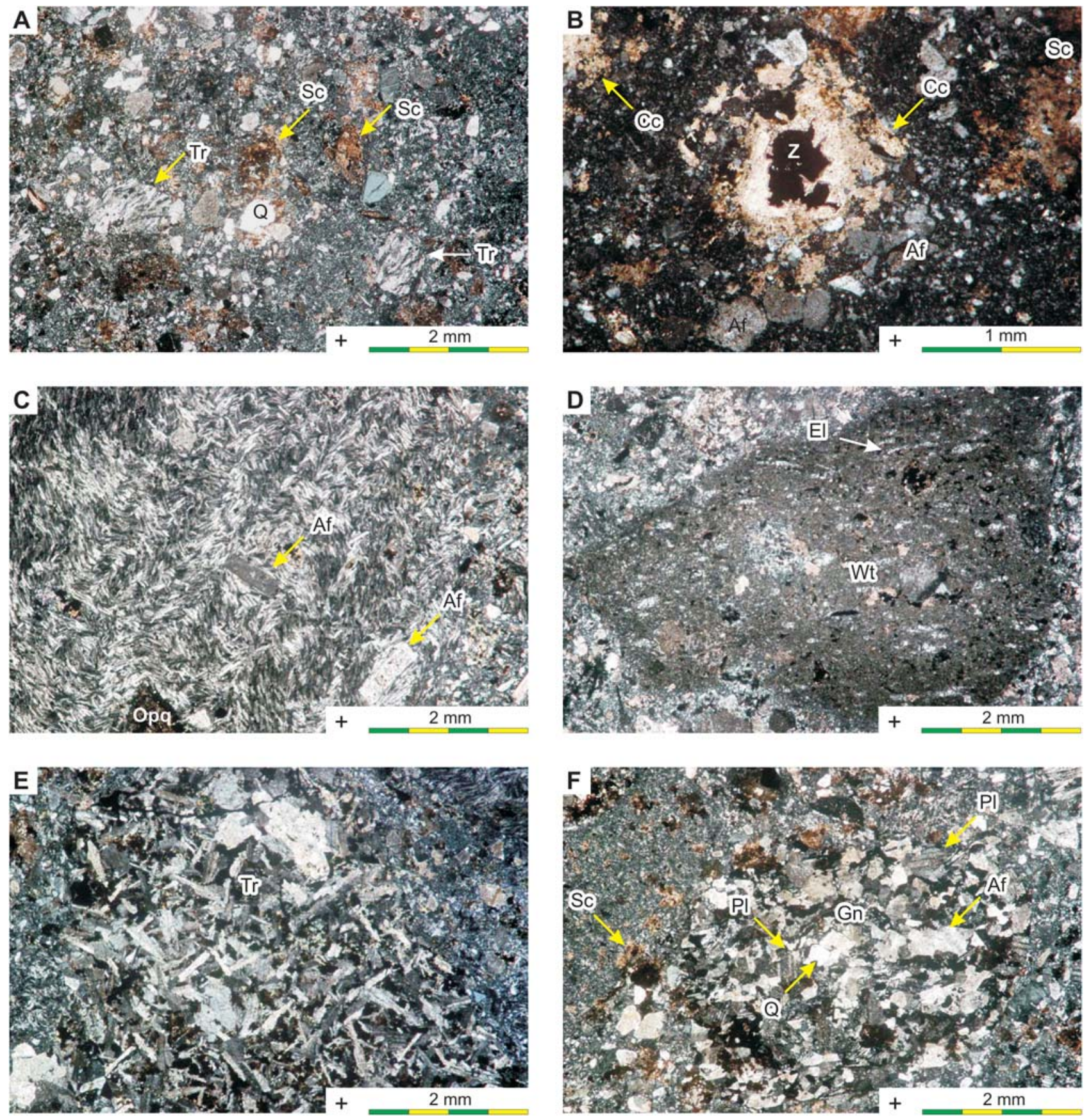

Figure 9 - Photomicrography of the pyroclastic rocks: A) Relatively gross-grained trachyte clasts and mineral fragments, Loc. 6; B) Cavity filled by zeolite and calcite, Loc. 10; C) Fine-grained large trachyte clast, Loc. 11; D) Welded tuff fragment with devitrified essential lenses, Loc. 6; E) Relatively gross-grained trachyte clast with interstitial texture, Loc. 11; F) Orthogneiss fragment, Loc. 6. The components are: Q. quartz; PI. plagioclase; Af. alkaline feldspar; Opq. opaque minerals; Cc. calcite; Z. zeolite; Sc. sericite; El. devitrified essential lens; Tr. trachyte clast; Wt. welded tuff clast. All images with crossed nicols. 
clasts indicate that the trachytic magma had enough cooling time to form the welldeveloped microliths and the interstitial texture. Therefore, the trachyte is not originated from lava flows, but a relatively large intrusive rock body. The microlith size suggests that the mother trachytic body could be larger than the dykes and sills of rapid cooling found around the syenitic body of Cabo Frio Island, but much smaller that the syenitic intrusion of very slow cooling.

There are also fragments of millimetric size with equigranular texture made up of alkaline feldspar, quartz, plagioclase, and opaque minerals, 0.2 to $0.4 \mathrm{~mm}$ in mineral size (Figure 9F). The sericitization of the alkaline feldspar is common and the mafic minerals are altered into opaque ones. Due to the mineral composition, these clasts are interpreted to be small fragments of orthogneiss.

The welded tuff clasts contain essential lenses of $0.08 \times 0.7 \mathrm{~mm}$, so-called fiamme. They are devitrified and substituted by chalcedony (Figure 9D). The aspect ratio, that is, the proportion between length and width, of the essential lenses is 7 to 10 , which is comparable with that of pyroclastic flow deposits of high grade welding.

Vent-filling welded tuff breccias emplaced at kilometric depth are characterized by extreme welding and secondary-flow textures (Motoki \& Sichel, 2006). The ratio aspect of the essential lenses is very high, more than 100 , and the texture becomes similar to that of rhyolite lavas (Motoki, 1979). In addition, some of Brazilian felsic alkaline pyroclastic bodies are submitted to strong hydrothermal alteration (e.g. Ellert, 1959; Ulbrich 1984; Motoki et al., 2007c). Therefore, the welded texture of the vent-filling felsic alkaline tuff breccia is often very difficult to be recognized even under microscope. In this sense, the relatively low-grade welding of the pyroclastic clasts suggests that they are not originated from deep sites of volcanic conduit, but from shallow sites.

\section{Emplacement mode}

In literature, pyroclastic rocks are interpreted commonly as constituent of subaerial eruptive deposits, and welded pyroclastic rocks are often attributed to pyroclastic flow deposits, so-called "ignimbrite". However, not all pyroclastic rocks, including welded tuff, are surface deposits. Some of them are constituent of subvolcanic bodies that fed pyroclastic materials to the surface, such as vents, necks, and fissures. Only a few papers on subvolcanic pyroclastic rock bodies are available and most of them have been published in Japan and Brazil (e.g. Motoki, 1979; Maeda et al., 1983; Miura, 1999; Bryan, et al., 2000; TorresHernández, et al., 2006; Motoki \& Sichel, 2006; Motoki et al., 2007a; b; c; 2008a).

The pyroclastic rocks of subaerial eruptive deposits and those of subvolcanic conduits have similar lithologic aspects and they are difficult to be distinguished in some cases (Motoki, 1979; 1988). The pyroclastic bodies of Mendanha, Nova Iguaçu (Motoki et al., 2007a; b; c), and Itaúna, São Gonçalo (Motoki et al., 2008a), are examples of subvolcanic bodies that once had been interpreted to be subaerial deposits (Klein \& Vieira, 1980; Klein et al., 1999). Therefore, geologic emplacement must be defined by field observations, especially of contact outcrops, and not by deduction based on lithologic and petrographic characteristics.

In order to determine the geologic emplacement mode, it is necessary to take into consideration the following aspects: the contact plane between the pyroclastic body and adjacent one is subvertical or subhorizontal; the distribution area is small or widespread; the clasts are relatively rounded or highly angular; the clasts size is heterogeneous or relatively well sorted; the texture is heterogeneous or characterised by developed layering. Vent-filling tuff breccias generally have subvertical contact, limited distribution area, relatively rounded clasts, heterogeneous clast size, and almost complete absence of volcanic layering.
The field observations of the pyroclastic body of Cabo Frio Island show that: 1) The contact is intrusive and sub-vertical (Figure 2); 2) The distribution area is small, $500 \mathrm{~m} \times 600 \mathrm{~m}$, and not of kilometric extension (Figure 1);3) Large clasts are semi-rounded (Figure 8B; D); 4) The clast size is heterogeneous (Figure 8A; B); 5) No layering is present (Figure 8A; B; D). These characteristics together support the model of vent-filling welded tuff breccia. The pyroclastic rocks of Cabo Frio Island have similar geologic and lithologic characteristics to those of other felsic alkaline complex bodies, such as Poços de Caldas, Minas Gerais (Motoki, 1988), Mendanha, Nova Iguaçu, Rio de Janeiro, (Motoki \& Sichel, 2006; Motoki et al., 2007a; c) and Itaúna, São Gonçalo, Rio de Janeiro (Motoki et al., 2008a).

The syenitic body of Cabo Frio Island proves that the present exposures correspond to a lower level of the intrusion (Motoki et al., 2008b). Fission track datings for apatite of the metamorphic basement of Rio de Janeiro region indicate Cenozoic regional uplift and consequent denudation of about 3 km (Hackspacher et al., 2004; Motoki et al., 2006). Therefore the present outcrops of the pyroclastic body might represent the subvolcanic structures located about $3 \mathrm{~km}$ below the Earth's surface at the time of magmatism (Figure 10).

\section{Conclusions}

The field observations and thin section studies of the pyroclastic rock of Cabo Frio Island allow the following conclusions:

1. The pyroclastic rocks are exposed in a small area, about $500 \times 600 \mathrm{~m}$. This body is intruded by the syenitic body of Cabo Frio Island.

2. The contact with the orthogneiss is intrusive and subvertical. Between the orthogneiss and pyroclastic rock, an intercalation of trachyte, 5 to $10 \mathrm{~m}$ wide, is present. 
3. The pyroclastic rocks show a clastmatrix supported structure. The clast size is highly variable, ranging from $1 \mathrm{~mm}$ to $40 \mathrm{~cm}$ in diameter. The clasts larger than $10 \mathrm{~cm}$ are semi-rounded and those smaller than $5 \mathrm{~cm}$ are angular.

4. The clasts are constituted mainly by trachyte, subordinately by orthogneiss, and eventually by welded tuff. The welded tuff clasts indicate that explosive eruptions occurred repeatedly.

5. The texture is highly heterogeneous and no sorting and layering are observed.

6. Microscopic observations reveal hydrothermal alteration of the pyroclastic rocks featured by calcite dissemination, alkaline feldspar sericitization, and mafic mineral decomposition.

7. The trachyte clasts show textural variation ranging from fine trachytic texture made up of microliths of 0.02 $\mathrm{x} 0.1 \mathrm{~mm}$, to interstitial texture of tabular alkaline feldspar of 0.1 x 0.5 $\mathrm{mm}$.

8. The existence of the welded tuff clasts indicates that explosive volcanism took place repeatedly.

9. Subvertical intrusive contact, small distribution area, rounded clasts, heterogeneous clast size, and absence of volcanic layering indicate that the pyroclastic rocks are not of subaerial eruptive deposit or volcanic edifice, but vent-filling welded tuff breccia emplaced at a deep site.

\section{Acknowledgement}

The authors are grateful to the FAPERJ, Carlos Chagas Filho Foundation, of the Rio de Janeiro State Government, which supported research projects related to the present article: Financial support category APQ1, "Petrologia, geoquímica e magmagêneses dos corpos alcalinos da ilha de Cabo Frio e Morro de São João e seus aspectos

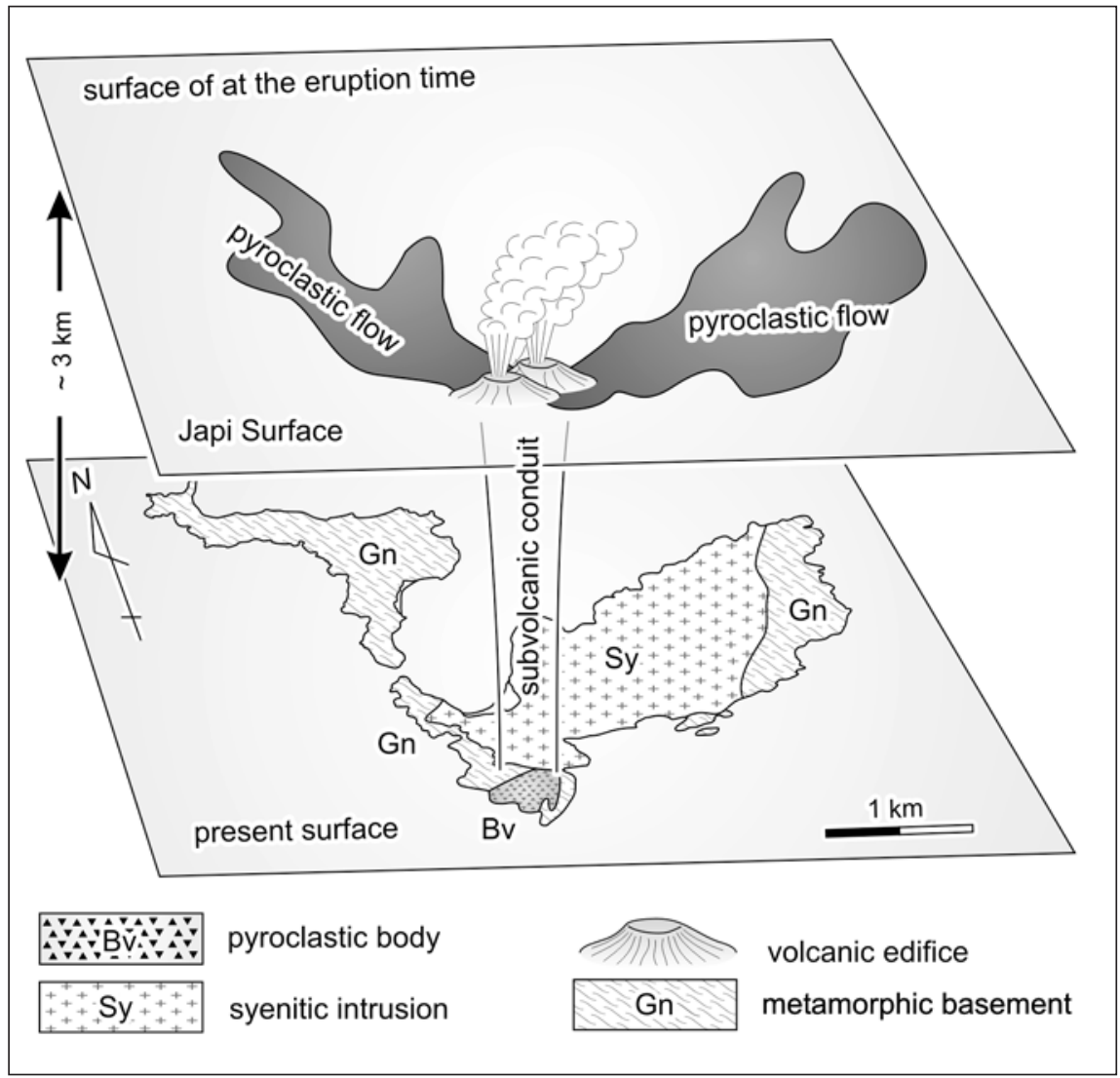

Figure 10 - Geologic emplacement model for the pyroclastic body of Cabo Frio Island.

ambientais como patrimônios geológicos"; Scholarship category IC, "Geologia e petrografia de corpos subvulcânicos como indicadores de atividades magmáticas subterrâneas e mecanismo de erupções vulcânicas”.

\section{Reference}

ARAÚJO, A.L. Geologia, geoquímica e petrologia das rochas alcalinas da ilha do Cabo Frio e das áreas continentais adjacentes, Arraial do Cabo - RJ. Niterói, Brazil: Department of Geology, Federal Fluminense University, (LAGEMAR/UFF), 1995. 114p. (Master Theses - unpublished).

BENNIO, L., BROTZU, P., D’ANTONIO, M., FERAUD, G., GOMES, C. B., MARZOLI, A., MELLUSO L., MORBIDELLI, L., MORRA, V., RAPAILLE, C. \& EXCELSO, R. The tholeiitic dyke swarm of the Arraial do Cabo peninsula (SE Brazil): ${ }^{39} \mathrm{Ar} /{ }^{40} \mathrm{Ar}$ ages, petrogenesis, and regional significance. Journal of South American Earth Sciences, v. 16, n. 2, p. 163-176, 2003. BROTZU, P., GOMES, C.B., MELLUSO, L., MORBIDELLI, L., MORRA, V., RUBERTI, E. Petrogenesis of coexisting
$\mathrm{SiO}_{2}$-undersaturated to $\mathrm{SiO}_{2}$-oversaturated felsic igneous rocks: The alkaline complex of Itatiaia, southeastern Brazil. Lithos, v. 40, p. 133-156, 1997.

BRYAN, S.E., EWART, A., STEPHENS, C.J., PARIANOS, J., DOWNES, P.J. The Whitsunday Volcanic Province, Central Queensland, Australia: lithological and stratigraphic investigations of a silicicdominated large igneous province. Journal of Volcanology and Geothermal Research, v. 99, n. 1-4, p. 55-78, 2000.

CAMPOS NETO, M.C., CABY, R. Terrane accretion and upward extrusion of highpressure granulites in the Neoproterozoic nappes of southeast Brazil: Petrologic and structural constraints. Tectonics, v. 19, n. 4, p. 669-687, 2000.

ELLERT, R. Contribuição geológica do maciço alcalino de Poços de Caldas. Boletim de Faculdades de Filosofica, Ciência e Letras, Universidade de São Paulo, v. 237, Geologia n. 18, p. 1-64, 1959.

GUEDES, E., HELIBRON, M., VASCONCELOS, P.M., VALERIANO, C.M., ALMEIDA, J.C.H., TEIXEIRA, W., THOMÁZ FILHO, A. K-Ar and ${ }^{40} \mathrm{Ar} /{ }^{39} \mathrm{Ar}$ 
ages of dykes emplaced in the on-shore basement of the Santos Basin, Resende area, SE. Brazil: implications for the south Atlantic opening and Tertiary reactivation. Journal of South American Earth Sciences, v. 18, p. 371-182, 2005.

HACKSPACHER, P.C., RIBEIRO, L.F.B., RIBEIRO, M.C.S., FETTER, A.H., HADLER, J.C.N., TELLO, C.A.S, DANTAS E.L.S. Consolidation and Breakup of the South American Platform in Southeastern Brazil: Tectonothermal and Denudation Histories. Gondwana Research, v. 7, n. 1, p. 91-101, 2004.

KLEIN, V.C., VALENÇA, J.G, ANDREIS, R.R., RAMOS, R.C. Depósitos vulcanoclásticos em Itaúna (RJ): análise preliminar de sua estratigrafia, estrutura e composição. Anais da Academia Brasileira de Ciências, Rio de Janeiro, v. 71, n. 1, p. 153, 1999. (Resumos de comunicações).

KLEIN, V.C., VIEIRA, A.C. Vulcões do Rio de Janeiro: breve geologia e perspectivas. Mineração Metalurgia, v. 419, p. 44-46, 1980.

LIMA, P.R.A.S. Geologia dos maciços alcalinos do Estado do Rio de Janeiro. Parte I - localização e geologia dos maciços. Semana de Estudos Geológicos, Universidade Federal Rural do Rio de Janeiro, p. 205-245, 1976. (unpublished)

MACDONALD, G.A. Volcanoes. PrenticeHall, Englewood Cliffs, 1972. 510 p.

MAEDA, K., TONODA, K., SUZUKI, T. The Geological Outline of the Undersea Portion of the Seikan Tunnel. Journal of the Japan Society of Enginnering Geology, v. 24, n. 3, p. 113-123, 1983.

MIURA, D. Arcuate pyroclastic conduits, ring faults, and coherent floor at Kumano caldera, southwest Honshu, Japan. Journal of Volcanology and Geothermal Reserach, v. 92, n. 3-4, p. 271-294, 1999.

MOTOKI, A. An outline about problems of volcanic caldera hypothesis of the Poços de Caldas Alkaline Complex Rock Body, Minas Gerais - São Paulo, Brazil. In: CONGRESSO LATINOAMERICANO DE GEOLOGIA, 7. Anais... v. 1, p. 309-323. 1988.

MOTOKI, A. Cretaceous volcanic vents in southeast part of Mt. Rokko, western Honshu, Japan. Bulletin of the Volcanological Society of Japan, v. 24, n. 2, p. 55-72, 1979.

MOTOKI, A., NETO, A.M., SICHEL, S.E., AIRES, J.R., SOARES, R., LOBATO, M.
2006. História de denudação regional e profundidade de posicionamento geológico das rochas vulcânicas de Nova Iguaçu, maciço Mendanha, RJ: constituintes de um vulcão ou corpos subvulcânicos ? In: CONGRESSO BRASILEIRO DE GEOLOGIA, 43. Anais... Aracaju, SBG, p. 136, 2006.

MOTOKI, A., PETRAKIS, G.H., SICHEL, S.E., CARDOSO, C.E., MELO, R.C., SOARES, R., MOTOKI, K.F. Origem dos relevos do maciço Sienítico do Mendanha, RJ, com base nas análises geomorfológicas e sua relação com a hipótese do Vulcão de Nova Iguaçu. Geociências, Rio Claro, 2008b. (in press).

MOTOKI, A., SICHEL, S.E. Avaliação de aspectos texturais e estruturais de corpos vulcânicos e subvulcânicos e sua relação com o ambiente de cristalização, com base em exemplos do Brasil, Argentina e Chile. REM - Revista Escola de Minas, v. 59, n. 1, p. 13-23, 2006.

MOTOKI, A., SICHEL, S.E. Hydraulic fracturing as a possible mechanism of dykesill transitions and horizontal discordant intrusions in trachytic tabular bodies of Arraial do Cabo, State of Rio de Janeiro, Brazil. Geofísica Internacional, México, v. 47, v. 1, p. 13-25, 2008.

MOTOKI, A., SICHEL, S.E., SOARES, R., NEVES, J.L.P., AIRES, J.R. Geological, lithological, and petrographical characteristics of the Itaúna Alkaline Intrusive Complex, São Gonçalo, State of Rio de Janeiro, Brazil, with special attention of its emplace mode. Geociências, Rio Claro, 2008a. (in press).

MOTOKI, A., SOARES, R., LOBATO, M., SICHEL, S.E., AIRES, J.R. Feições intempéricas em rochas alcalinas félsicas de Nova Iguaçu, RJ. REM - Revista Escola de Minas, v. 60, n. 3, p. 451-458, 2007b.

MOTOKI, A., SOARES, R., NETTO, A.M., SICHEL, S.E., AIRES, J.R., LOBATO, M. Reavaliação do modelo genético do vulcão de Nova Iguaçu, RJ: origem eruptiva ou intrusão subvulcânica? REM - Revista Escola de Minas, v. 60, n. 4, p. 583-592. 2007a.

MOTOKI, A., SOARES, R., NETTO, A.M., SICHEL, S.E., AIRES, J.R., LOBATO, M. Forma de ocorrência geológica dos diques de rocha piroclástica no Vale do Rio Dona Eugênia, Parque Municipal de Nova Iguaçu, RJ. Geociências, Rio Claro, v. 26, n. 1, p. 67-82. 2007c.
PEATE, D.W., HAWKESORTH, C.J. \& MANTOVANI, M.S.M. Chemical stratigraphy of the Paraná lavas (South America): classification of magma types and their spatial distribution. Bulletin of Volcanology, v. 55, p. 119-139, 1992.

SCHMITT, R.S., TROUW, R.A.J., VAN SCHMUS, R., PASSCHIER, C.W. In: Cambrian orogeny in the Ribeira Belt (SE Brazil) and correlations within West Gondwana: ties that bind underwater. Pankhurst, R.J., Trouw, R.A., Brito Neves, B.B., De Wit, J.J. Eds. West Gondwana: Pre-Cenozoic Correlations Across the South Atlantic Region. Geological Society of London, Special Publications, v. 294, p. 279-296, 2008.

SICHEL, S.E., ARAÚJO, A.L.N., GUEDES, E., MANSUR, K., GUIMARÃES, P., MEDEIROS, F., MAJDALANI, S. Arraial do Cabo - ilha do Cabo Frio (ilha do Farol). Homepage do Departamento de Recursos Minerais do Estado do Rio de Janeiro (DRM-RJ), http:// www.drm.rj.gov.br/item.asp?chave=121, 2004: Acesso 24 de junho de 2006.

TORRES-HERNÁNDEZ, J.R., LABARTHEHERNÁNDEZ, G., AGUILLÓN-ROBES, A., GÓMEZ-ANGUIANO, M., MATASEGURA, J.L. The pyrolcastic dykes of the Tertiary San lui Potosí volcanic field: Implications of the emplacemet of Panalillo ignimbrite. Geofísica Internacional, Cuidad del Mexico, v. 45, n. 4, p. 243-253, 2006.

TURNER, S., REGELOUS, M., KELLEY, S., HAWKESWORTH, C. \& MANTOVANI, M. Magmatism and continental break-up in the South Atlantic: high precision ${ }^{40} \mathrm{Ar} /{ }^{39} \mathrm{Ar}$ geochronology. Earth and Planetary Science Letters, v. 121, p. 333-348, 1994.

ULBRICH, H.H.G.J. A petrografia, a estrutura e quimismo de nefelina sienitos do maciço alcalino de Poços de Caldas, MG-SP. Instituto de Geociências da Universidade de São Paulo, 1984. 360p. (Tese de Livre Docência - unpublished).

ULBRICH, H.H.G.J., GOMES, C.B. Alkaline igneous rocks from continental Brazil. Earth Science Review, v. 17, p. 135-154, 1981.

\section{Artigo recebido em 03/01/2008 e aprovado em 17/07/2008.}

